\title{
PENINGKATAN KEMAMPUAN MANAJEMEN, PRODUKSI, DAN PEMASARAN JASA BAGI WIRAUSAHAWAN PEMULA FOTOGRAFI DAN VIDEOGRAFI DI BLITAR
}

\author{
Nilawati Fiernaningsih $^{1 *}$, Pudji Herijanto ${ }^{2}$, Ita Rifiani ${ }^{3}$, Eko Boedhi Santoso ${ }^{4}$, Mustofa Hadi ${ }^{5}$ \\ 1,2,3,4,5 Jurusan Administrasi Niaga, Politeknik Negeri Malang \\ *Email Korespondensi: nilafh@yahoo.co.id
}

\begin{abstract}
ABSTRAK
Latar belakang permasalahan rintisan usaha baru, adalah belum dikenal dan masih minim pengalaman. Selain itu pengetahuan dan keterampilan manajemen usaha juga sangat minim, wira usaha muda dengan bekal yang ada, membuka usaha jasa fotografi dan usaha jasa videografi. Hal berdasarkan hasil diskusi dengan mitra mereka ternyata belum memiliki rencana bisnis yang terstruktur. Selain itu wirausaha muda juga belum menyusun rencana pemasaran yang jelas. Pemahaman tentang product knowledge juga masih terbatas. Rencana bisnis adalah suatu dokumen yang dibuat seseorang yang ingin membuka bisnis atau seseorang yang sudah menjalankan bisnis. Rencana bisnis memberikan gambaran yang lengkap mengenai bisnis dan rencana-rencananya untuk kurun waktu tertentu (misalnya dari satu sampai lima tahun). Perencanaan pemasasaran (marketing planning) adalah suatu bagan dari suatu desain untuk mencapai suatu tujuan. Tujuannya adalah untuk menciptakan nilai bagi konsumen dalam kondisi tetap menguntungkan perusahaan atau dalam konsep pemasaran saat ini, suatu hubungan yang saling menguntungkan. Melihat latar belakang pelaku yang minim dengan bekal pengetahuan dan pengalaman dalam mengelola usaha, maka solusi pertama yang ditawarkan adalah membekali manajemen usaha. Secara komprehensif dilakukan dengan membekali pengetahuan dan praktek merencanakan usaha. Solusi ini diberikan untuk merumuskan kembali dengan lebih baik tentang usaha yang dijalankan. Kemudian mengidentifikasi masing-masing aspek bisnis yang dimilikinya. Dengan demikian mereka akan lebih memahami usaha yang akan dijalankannya. Solusi berikutnya adalah dibekali pengetahuan dan keterampilan menyusun rencana pemasaran. Dengan rencana pemasaran mereka akan dapat menerapkan sumber daya pemasaran untuk mencapai tujuan pemasaran. Dengan diwujudkannya tujuan pemasaran sudah barang tentu akan mewujudkan tujuan usahanya.
\end{abstract}

Kata kunci : Pemasaran, Perencanaan, Usaha Jasa Video dan Photografi

\begin{abstract}
The background of the problem of piloting a new business is that it is unknown and still lacks experience. Besides, the knowledge and skills of business management are also very minimal, young entrepreneurs with existing stock, opening a photography service business and videography services business. Based on the results of discussions with their partners, they do not yet have a structured business plan. Besides, young entrepreneurs have not yet developed a clear marketing plan. Understanding of product knowledge is also still limited. A business plan is a document made by someone who wants to open a business or someone who has run a business. The business plan provides a complete picture of the business and its plans for a specified period (for example, from one to five years). Targeting planning (marketing planning) is a chart of a design to achieve a goal. The aim is to create value for consumers in conditions that still benefit the company or in the current marketing concept, a mutually beneficial relationship. Seeing the background of the offender who is lacking with the knowledge and experience in managing the business, the first solution offered is to provide business management. Comprehensively carried out by providing knowledge and practice of business planning. This solution is given to reformulate better the business being run. Then identify each aspect of the business that it has. Thus they will better understand the business that will be carried out. The next solution is to be equipped with knowledge and skills in preparing marketing plans. With the marketing plan, they will be able to apply marketing resources to achieve marketing goals. With the realisation of marketing objectives, of course, will realise the business objectives.
\end{abstract}

Keywords: Marketing, Planning, Business Services Video and Photography 


\section{PENDAHULUAN}

Latar belakang program Pengabdian Kepada Masyarakat ini bertujuan para Ahli Muda bidang Pengolahan Audio dan Video yang baru mengantongi Ijazah Diploma Dua. Sebagai Ahli Muda, pengetahuan dasar dan keterampilan baik dalam menghasilkan produk-produk fotografi dan video grafi yang memenuhi standar bidang tersebut. Mereka juga telah mendapatkan mata-kulian Kewirausahaan (Budi \& Ghazali, 2015; Nugroho \& Cahyadin, 2010).

Dengan bekal yang ada, mereka memberanikan diri memulai berwirausaha. Mereka mengkhususkan diri menjadi usaha jasa fotografi dan usaha jasa videografi.Hal ini perlu diapresiasi dan didukung agar mereka dapat berkembang menjadi wirausahawan yang sesungguhnya. Mengingat sampai sekarang ini jumlah wirausahawan lulusan perguruan tinggi masih sangat sedikit. Di lain pihak seperti disampaikan oleh Ir. Hari Purwanto MSc DIC, staf Ahli Menristekdikti Bidang Infrastruktur, bahwa: "Pada 2035, Indonesia diramalkan akan menjadi ekonomi terbesar ke-4 setelah China, India, dan Amerika. Menurut, Presiden JokoWidodo, pada 2030, Indonesia di nomor 7, artinya perlu lompatan untuk jadi ke-4 dari 2030 ke 2035," katanya. "Untuk capai ini, kita perlu ciptakan wirausaha kuat. Ini satu-satunya, bagimana kita memilih positioning perekonomian dunia yang penuh keterbukaan dan inovasi distruptif, ujarnya mengakhiri sambutan. (https://www.ristekdikti.go.id/dorong-mahasiswa-jadi-wirausaha/25Nov2017). Sangat mungkin merekalah yang ke depan akan menjadi wirausahawan kuat yang akan ikut menentukan positioning perekonomian Indonesia (Parasuraman, et al., 1985; Parasuraman, et al., 1988; Rushadi, et al., 2016; Sentiko, 2016).

\section{METODE}

Guna menyelesaikan permasalahan yang dihadapi mitra, metode pendekatan yang dilakukan adalah dengan pendekatan praktis yang mengacu pada konsep dasar permasalahan. Dengan demikian pendekatan penyelesaian permasalahan akan didahului dengan peningkatan pengetahuan bisnis mitra. Peningkatan pengetahuan yang diberikan adalah sebagai berikut:

a. Peningkatan Pemahaman Jasa,yang dilakukan dengan:

- Mitra diberi ceramah singkat tentang konsep Jasa dan Karakteristik Jasa, yang dilanjutkan dengan proses diskusi. Setelah itu mitra diminta merangkum secara tertulis pemahaman mereka tentang materi yang telah dibahas. Hal ini untuk membantu mitra bisa lebih memahami, karena ada proses internalisasi dengan menuliskan hasil pemahamannya.

- Setelah itu mitra diminta menerapkan hasil pemahaman konsep jasa pada jasa yang akan mereka bisniskan. Hal ini dilakukan dengan presentasi oleh masing-masing kelompok usaha.

b. Peningkatan Pemahaman dan Keterampilan Menyusun Rencana Usaha Jasa, yang dilakukan dengan:

- Mengingat mitra sudah pernah mendapatkan kuliah Kewirausahaan, untuk meningkatkan pengetahuannya dilakukan dengan metode diskusi.

- Jika dinilai sudah mencukupi maka langsung dipandu untuk menyusun rencana bisnis.

- Hasil yang mereka susun dipresentasikan di depan Tim PkM dan kelompok lain.

c. Peningkatan Pemahaman dan Keterampilan Menyususn Rencana Pemasaran Jasa,yang dilakukan dengan:

- Rencana Pemasaran bagi mitra merupakan hal baru. Untuk itu perlu diberi ceramah singkat tentang materi tersebut, yang dilanjutkan dengan proses diskusi. Kemudian dilakukan proses internalisasi dengan menuliskan hasil pemahaman mereka tentang Rencana Pemasaran Jasa. 
- Kemudian mitra diminta berlatih menyusun Rencana Pemasaran Jasa, dan hasilnya dipresentasikan didepan Tim PkM dan kelompok lain.

d. Simulasi Penerapan Manajemen Usaha

Seperti telah disinggung sebelumnya pada Bab 3 dilakukan simulasi saling menerima order pembuatan Company Profile. Kedua kelompok saling membuatkan Company Profile dengan menerapkan ketiga materi pengelolaan usaha yang telah diperolehnya.

e. Penerapan Manajemen Usaha

Tibalah saatnya mitra menerapkan semua materi yang telah diperoleh untuk menjalankan usaha mereka yang sesungguhnya. Diharapkan tahap awal mereka menjalankan usahanya setelah mengikuti program PkM ini masih bisa dipantau oleh Tim. Sehingga bisa diketahui dampak nyata yang dialami oleh mitra setelah mengikuti program PkM ini.

\section{HASIL DAN PEMBAHASAN}

Dalam pelaksanaan PkM ini ada beberapa tahap yang dilaksanakan yaitu antara lain :

Tahap Partisipasi

Partisipasi mitra dalam pelaksanaan program seperti Gambar 1 adalah sebagai berikut:

a. Menyediakan tempat kegiatan PkM. Mengingat mitra belum memiliki tempat usaha yang khusus, mitra masih menggunakan rumah orang tua sebagai alamat formal mereka. Kegiatan mereka hamper selalu dilakukan di kampus. Untuk kegiatan PkM ini mereka juga merencanakanakan meminjam tempat di kampus mereka.

b. Membantu mencarikan tempat peminjaman kelengkapan pelaksanaan PkM, sehingga Tim tidak perlu membawa atau meminjam dari Malang.

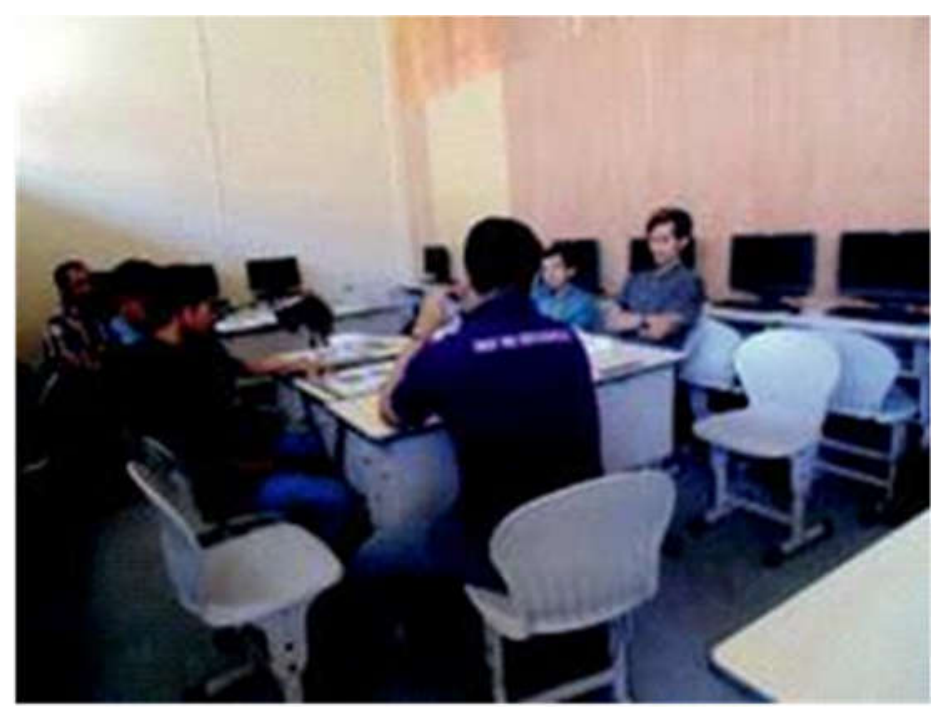

Gambar 1. Partisipasi Mitra

\section{Tahap Pelatihan}

Dari latar belakang mitra yang minim dengan bekal pengetahuan dan pengalaman dalam mengelola usaha, maka solusi pertama yang ditawarkan adalah membekali manajemen usaha. Secara komprehensif dilakukan dengan membekali pengetahuan dan praktek merencanakan usaha. Solusi ini diberikan untuk merumuskan kembali dengan lebih baik tentang usaha yang dijalankan. Kemudian mengidentifikasi masing-masing aspek bisnis yang dimilikinya. Dengan demikian mereka akan lebih memahami usaha yang akan dijalankannya.

Solusi berikutnya adalah dibekali pengetahuan dan keterampilan menyusun rencana pemasaran. Dengan rencana pemasaran mereka akan dapat menerapkan sumberdaya 
pemasaran untuk mencapai tujuan pemasaran. Dengan diwujudkannya tujuan pemasaran sudah barang tentu akan mewujudkan tujuan usahanya.

Mengingat mereka menjalankan usaha dalam bidang jasa, maka pembekalan pengetahuan tentang jasa dan karakteristik jasanya perlu mereka pahami. Hal ini dikarenakan selama ini pemahaman mereka adalah menghasilkan produk berupa foto dan video. Dengan demikian mereka lebih memahami karakteristik usahanya.

Setelah itu didampingi menerapkan ketiga konsep yang telah diberikan, paling tidak minimal untuk satu periode penjualan jasanya. Penerapan ini dimulai dengan simulasi menerima jasa penyusunan company profile. Karena mereka terdiri dari dua kelompok usaha, mereka akan saling menerima order company profile. Mereka akan membuat perencanaan yang baik, kemudian mengimplementasikan perencanaannya dan mengevaluasi apa yang telah dilakukannya seperti pada Gambar 3.
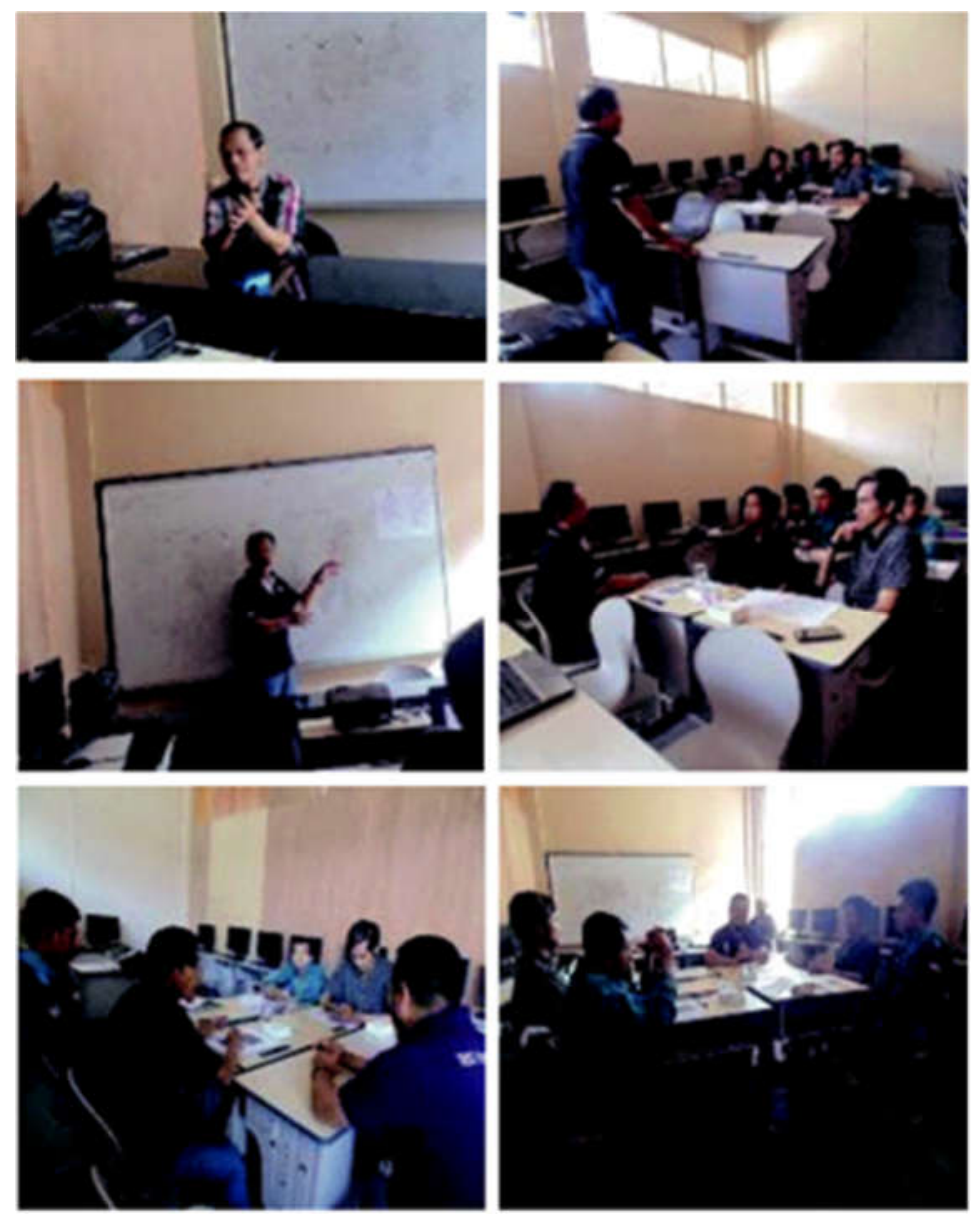

Gambar 2. Pelatihan

\section{Tahap Evaluasi}

Evaluasi pelaksanaan kegiatan dilakukan sesuai dengan tahapan dalam metode pendekatan penyelesaian permasalahan seperti pada Gambar 3 adalah sebagai berikut:

a. Peningkatan Pemahaman Jasa. Untuk mengevaluasi tentang pemahaman mereka terhadap konsep Jasa dan Karakteristik Jasa dilakukan dengan presentasi oleh masingmasing kelompok usaha. Selain itu juga untuk lebih menfokuskan lingkup jasa yang akan mereka tawarkan dalam bisnis mereka.

b. Peningkatan Pemahaman dan Keterampilan Menyususn Rencana Usaha Jasa. Tahapan ini juga dilakukan dengan presentasi. Mitra mempresentasikan Rencana Usaha Jasa yang 
telah mereka susun di depan Tim PkM dan kelompok lain. Hal ini untuk mengevaluasi tingkat pengetahuan dan keterampilan dalam menyusun rencana usaha.

c. Peningkatan Pemahaman dan Keterampilan Menyususn Rencana Pemasaran Jasa juga dilakukan dengan presentasi. Mereka mempresentasikan Rencana Pemasaran mereka didepan Tim PkM dan kelompok lain.

d. Simulasi Penerapan Manajemen Usaha. Tujuan dari simulasi ini adalah selain sebagai bahan evaluasi secara komprehensif terhadap semua materi yang telah diterima. Selain itu juga untuk menambah pengalaman dalam menjalankan usahanya. Tujuan akhir yang diharapkan dari simulasi adalah masing-masing kelompok memiliki Company Profile sebagai sarana promosi, guna mengatasi permasalahan mereka yang belum dikenal.

e. Penerapan Manajemen Usaha. Di akhir program mitra menjalankan usahanya masingmasing, namun dalam konteks bersinergi, mereka saling mendukung untuk kesuksesan usahanya.
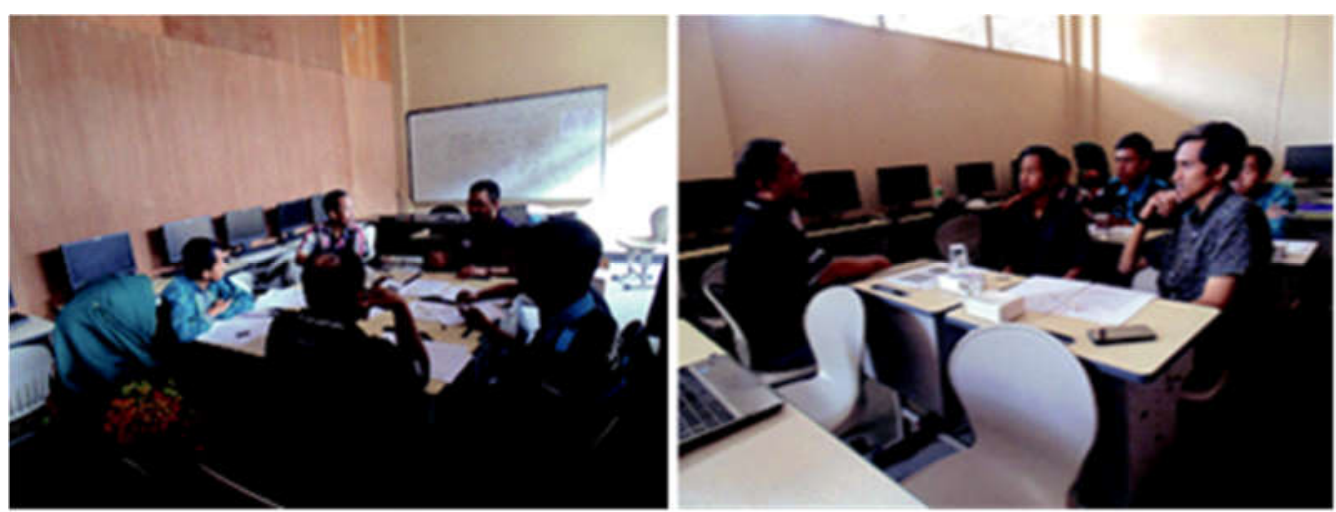

Gambar 3. Tahap Evaluasi

\section{DAMPAK DAN MANFAAT}

Melihat latar belakang pelaku yang minim dengan bekal pengetahuan dan pengalaman dalam mengelola usaha, maka solusi pertama yang ditawarkan adalah membekali manajemen usaha. Secara komprehensif dilakukan dengan membekali pengetahuan dan praktek merencanakan usaha. Solusi ini diberikan untuk merumuskan kembali dengan lebih baik tentang usaha yang dijalankan. Kemudian mengidentifikasi masing-masing aspek bisnis yang dimilikinya. Dengan demikian mereka akan lebih memahami usaha yang akan dijalankannya.

Solusi berikutnya adalah dibekali pengetahuan dan keterampilan menyusun rencana pemasaran. Dengan rencana pemasaran mereka akan dapat menerapkan sumberdaya pemasaran untuk mencapai tujuan pemasaran. Dengan diwujudkannya tujuan pemasaran sudah barang tentu akan mewujudkan tujuan usahanya.

Mengingat mereka menjalankan usaha dalam bidang jasa, maka pembekalan pengetahuan tentang jasa dan karakteristik jasanya perlu mereka pahami. Hal ini dikarenakan selama ini pemahaman mereka adalah menghasilkan produk berupa foto dan video. Dengan demikian mereka lebih memahami karakteristik usahanya.

Setelah itu didampingi menerapkan ketiga konsep yang telah diberikan, paling tidak minimal untuk satu periode penjualan jasanya. Penerapan ini dimulai dengan simulasi menerima jasap enyusunan company profile. Karena mereka terdiri dari dua kelompok usaha, mereka akan saling menerima order company profile. Mereka akan membuat perencanaan yang baik, kemudian mengimplementasikan perencanaannya dan mengevaluasi apa yang telah dilakukannya. 


\section{KESIMPULAN}

Peningkatan dan Pengembangan manajemen pemasaran jasa sebagai upaya peningkatan usaha. Dibutuhkan strategi dalam peningkatan usaha kreatif.

\section{REFERENSI}

Budi, W. S. dan Ghazali, A (2015) ‘Rencana Pengembangan Fotografi Nasional 2015-2019’, Penerbit PT. Republik Solusi Cetakan Pertama, Maret.

Nugroho, P. S., Cahyadin, M. (2010) 'Analisis Perkembangan Industri Kreatif Di Indonesia', Simposium Ekonomi Indonesia Pasca Krisis Ekonomi Global, Surabaya.

Parasuraman, A., Zeithaml, V. A. dan Berry, L. L. (1985) 'A Conceptual Model Of Service Quality And Its Implications For Future Research', The Journal of Marketing, 41-50.

Parasuraman, A., Zeithaml, V. A. dan Berry, L. L. (1988) 'SERVQUAL-A Multiple-Item Scale For Measuring Consumer Perceptions Of Service Quality', Journal of retailing, 64(1), 12-40.

Rushadi, B. S., Haripradianto, T. dan Santosa, H. (2016) 'Sekolah Fotografi Di Kota Malang Dengan Pendekatan Analisa Space Syntax', Jurnal Mahasiswa Jurusan Arsitektur, 4(2).

Sentiko, S. A. (2016) 'Strategi Alternatif Pada Big Bang Brain Creative (Bbb Creative) Berdasarkan Analisis SWOT', Doctoral dissertation, Fakultas Ekonomi dan Bisnis UNIKA Soegijapranata). 